\title{
Lexical and Phrasal Analysis of Online Discourse of Type 2 Diabetes Patients based on Text-Mining
}

\author{
Moonl-Hyon Hwang ${ }^{*}$, Jungsik Park ${ }^{* *}$ \\ Dept. of Applied Physiology and Kinesiology, University of Florida, Gainesville, FL, USA * \\ Dept. of English Language and Literature, Ajou University, Suwon, Korea ${ }^{\text {** }}$ \\ 텍스트마이닝 기법을 이용한 제 2형 당뇨환자 온라인 \\ 담론의 어휘 및 구문구조 분석 \\ 황문현 ${ }^{*}$, 박정식 ${ }^{* *}$ \\ 플로리다대학교 응용생리학 및 운동과학과 ${ }^{*}$ 아주대학교 인문대학 영어영문학과 ${ }^{* *}$
}

\begin{abstract}
This paper has identified five major categories of the T2D patients' concerns based on an online forum where the patients voluntarily verbalized their naturally occurring emotional reactions and concerns related to T2D. We have emphasized the fact that the lexical and phrasal analysis brought to the forefront the prevailing negative reactions and desires for clear information, professional advice, and emotional support. This study used lexical and phrasal analysis based on text-mining tools to estimate the potential of using a large sample of patient conversation of a specific disease posted on the internet for clinical features and patients' emotions. As a result, the study showed that quantitative analysis based on text-mining is a viable method of generalizing the psychological concerns and features of T2D patients.
\end{abstract}

Key Words : Type 2 Diabetes, Psychological Condition, Text-Mining, Lexical and Phrasal Analysis, Online Discourse.

요 약 본 연구는 질병과 관련한 온라인 포럼에서 추출한 언어 데이터를 통해 제 2형 당뇨병 환자의 질병에 대한 담론을 양적으로 분석하였다. 또한 환자 언어행위의 양적분석을 통해 환자들의 주요 관심사와 심리적 특징의 일반화 가 가능한지에 대해 실증적으로 검증하였다. 분석방법으로는 기존의 인터뷰에 기반한 정성적 연구방법론과 달리 환 자들의 담론 표본 전체를 파싱 (parsing)과 POS 태깅을 통해 언어학적으로 형태소 분류를 하였다. 주요 어휘빈도 추 출과 N-gram을 통한 최빈도 구문구조 분석을 병행하여, 질병과 관련한 이슈의 주요 범주와 심리상태에 관한 언어적 인 특징을 살펴보았다. 연구 결과 환자들의 자발적 대화는 주로 다이어트, 운동, 증상, 약물치료, 심리상태의 5 가지 범주로 나타나고 있음을 확인하였고, 최빈도 구문구조 분석을 통해 질병치료와 식생활습관 개선 전반에 대한 부정적 인 견해가 두드러진 것을 확인하였다. 결과적으로 의료진의 정확한 정보 전달과 전문가의 조언, 정서적 지원 등이 당뇨환자에 대한 심리적 상태에 중요한 만큼 심리치료 서비스이 개선이 필요할 것으로 보인다. 이런한 결과는 기존 의 의료제도 안에서의 환자의 관심사와 심리적 특징이 온라인 상에서도 적절하게 투영되고 있음을 시사한다.

주제어 : 제 2형 당뇨, 심리상태, 텍스트마이닝, 어휘 및 구문분석, 온라인 담론분석

Received 16 April 2014, Revised 8 May 2014

Accepted 20 June 2014

Corresponding Author: Jungsik Park

(Dept. of English Language and Literature, Ajou University)

Email: jspark@ajou.ac.kr
(C) The Society of Digital Policy \& Management. All rights reserved. This is an open-access article distributed under the terms of the Creative Commons Attribution Non-Commercial License (http://creativecommons.org/licenses/by-nc/3.0), which permits unrestricted non-commercial use, distribution, and reproduction in any medium, provided the original work is properly cited. 


\section{INTRODUCTION}

During the last couple of decades, Type 2 diabetes has been discussed regarding its etiology, pathogenesis, complications, social impacts and costs. Type 2 diabetes is a chronic and widespread disease that influences more than 300 million people world-wide and creates social and economic burdens for patients, families and national health care providers - with its cost of diagnosed diabetes in 2012 alone reaching \$245 billion [1]. Etiologically, diabetes has two broad but distinctive forms. Type 1 diabetes is an insulin-dependent diabetes mellitus and results from the functional loss of beta cells in a human pancreas. Insulin secretion is substantially limited, thus glucose molecules in the human blood stream are not likely to get into the cells. Type 2 diabetes is a non-insulin dependent diabetes mellitus and results from the increased resistance of insulin receptors when they combine with insulin despite normal or slightly less secretions of insulin. Compared to Type 1 diabetes, Type 2 diabetes possesses over $90 \%$ of total diabetic patients and is also known to be closely related to over-nutrition, obesity, and a sedentary lifestyle. Its chronic complications are major cardiovascular diseases, loss of visual acuity, and limb amputations, and there is no conclusive cure for this chronic disorder known so far [2], [3].

Despite medical and clinical studies with a wealth of accumulated data concerning the etiological and patho-generic development of type 2 diabetes (hereafter referred to as T2D), little research has been done on the T2D patients' online discourse on their physical conditions and psychological needs. Whereas other qualitative and ethnographic studies based on surveys and interviews have provided much insight into the experience the T2D patients undergo, this study attempts to identify and analyze the naturally occurring conversations where the patients voluntarily express their own concerns and where they do not need to follow structured questionnaires, and by so doing, this study avoids the homogeneity issues in their answers and explanations.

With the advent of Internet forums and other SNS platforms, it has become relevant to analyze the discourse of the T2D patients: contemporary patients tend to find forums to share their experience with others who have the same disease and/or disorders, and numerous accounts of experience and medication specific to T2D are available. Traditionally, data sets such as testimonial accounts derived from patients had been the usual sources of the qualitative studies on illness experience. Though the traditional sources have been analyzed as evidence of common illness experience, they lack in quantity to generalize the clinical features of a disease and patients' discourse related to them, and the amount of information archived in the disease-specific platforms is not sufficiently manageable. Thus a different method of approach is required. Only recently, discourse analysts, health specialists, researchers and scholars have noticed the possibilities for mining those unstructured language data and extracting, patterning, and analyzing the ever-growing text data [4].

The objective of this study is to explore online discourse on type 2 diabetes and to identify patients' concerns and psychological needs in an online forum organized by T2D patients. Apart from medical treatment, T2D patients undergo a different experience and situation with physical and psychological characteristics with a marked difference from non-patients. Therefore, this study aims to represent those characteristics of T2D patients and identify some of the shared areas of their concerns and their attitudes towards their experience of T2D through lexical and phrasal analysis and language patterning. 


\section{METHOD}

As known under the umbrella term 'text-mining'that is, data-mining of unstructured language datascholars from various disciplines, including health related professionals, have conducted identifying lexical, phrasal, or sentential patterns and thematic tendencies. They have suggested that massive amounts of data are more aptly studied by using text-mining methods than the qualitative approaches based on surveys and interviews [5], [6], [7]. The text-mining tasks such as text classification, clustering, word-frequency, and content analysis have been proven efficient at detecting the recurring patterns of clinical features and patients' concerns [8], [9].

The present study observes the conversation in the form of 'messages' and 'replies' related to T2D carriers posted on the chosen forum-'the Global Diabetes Community' where over 93,500 patients with diabetes and their family members share their experience, concerns, and information to better cope with the disease. By text-mining the discourse of the patients with T2D, our aim was first, to identify the recurring themes of T2D patients' concerns, and second, to interpret the patients' psychological conditions and welfare.

To study the current concerns of T2D patients and the characteristics of discourse on their diet and exercise, 400 patients' conversations were extracted as samples from the T2D group site titled the Global Diabetes Community' at < http://www.diabetes.co.uk /forum/category/type-2-diabetes.25/> that provides a platform where various types of patients can share the experience of the disease. First, the unstructured data of conversation about T2D were collected through a crawling process. The collected words were then tokenized and parts of speech (POS) were tagged by Stanford Log-Linear Part of Speech Tagger. AntConc 3.2.4 w was also used to arrange the words into the categories of verbs, nouns, and adjectives and to perform $\mathrm{N}$-gram analysis 1$)^{1}$. Along with the retrieval and classification of the information, a lexical and phrasal analysis was conducted based on $\mathrm{N}$-gram frequency ranking. In addition, Phrase Net visualization based on the web-based text-mining tool was used to check the phrase patterns and any two words that were connected with a conjunction ${ }^{2}$.

\section{RESULTS}

This study identified T2D related words and phrases of high frequency by conducting POS tagging, and by so doing, aimed to generalize distinctive features of conversation in the T2D patients' discourse. After data cleansing, which eliminated common words such as pronouns and personal proper nouns, we obtained 56,162 T2D related nouns. Among them, we chose 200 nouns with the highest frequency and identified five thematic categories manually: (1) Diet, (2) Exercise, (3) Symptoms, (4) Medication, and (5) Psychological Condition. For psychological condition, we then conducted additional analysis using $\mathrm{N}$-gram analysis to identify the patients recurring patterns of phrase expression.

\subsection{Diet}

According to the analysis of noun frequency from the conversation of T2D patients, food consumption

1) AntConc is a Concordancer that provides such functions as concordance, collocation, word frequency and keyword listing. More information is found at <http://www.antlab. sci.waseda.ac.jp>.

2) ManyEyes is created by Fernanda Viégas and Martin Wattenberg. It offers a graphic representation of patterns and distinctions of a given dataset. Constructed on a public web site, it allows users to upload a set of data, visualize them, and gain new insights into patterns occurring in the data. Information about Phrase Net and other functions of ManyEyes are available at <http://www-958.ibm.com /software/analytics/manyeyes/>. 
was one of the major concerns of the patients. The noun with the highest frequency (1) of occurrence was 'carb'(1), with such variance as 'carbs' and 'carbohydrates,' suggesting it is the most important word characterizing T2D (Appendix 1). General terms like 'diet'(7), 'food'(12), and 'meal'(15) showed the next highest frequency level, followed by specific terms such as 'bread'(39), 'potato'(59), 'rice'(67), and 'pasta'(77). The results met our expectation that controlling food consumption and limiting carbohydrate intake would be the most distinctive concern for T2D patients.

\subsection{Exercise}

In the category of 'Exercise,' the word 'exercise' was ranked first (21), followed by 'body'(34) 'loss'(65), 'walk'(80), 'lbs'(118), 'mile'(169), 'knee'(175), 'step'(187), and 'joint'(196). As shown in the analysis of the noun frequency (Appendix 1) and Phrase Net visualization (Figure 1), 'exercise' is the most frequent noun in the category of 'Exercise,' and most commonly associated with the terms of other categories such as 'Diet'indicating that patients feel that they need to do exercise in relation to diabetes care and it often goes with 'diet.' Slight variations in usage of the key words existed depending on the stages or aspects of exercise: the high frequency of the word 'lbs' indicates that T2D patients are interested in managing or reducing their body weight, whereas the words 'joint' and 'knee' that often occurred together indicate that T2D patients are concerned about discomfort or injuries from exercise. And the words 'mile' and 'step' appear to be dominant when T2D patients are conscious of increasing their level of physical activity.

\subsection{Symptom}

The nouns frequently related to symptoms of T2D are words such as 'blood'(2), 'level'(5), 'sugar'(8), 'insulin'(14), 'eye'(70), 'foot'(86), 'kidney'(176),

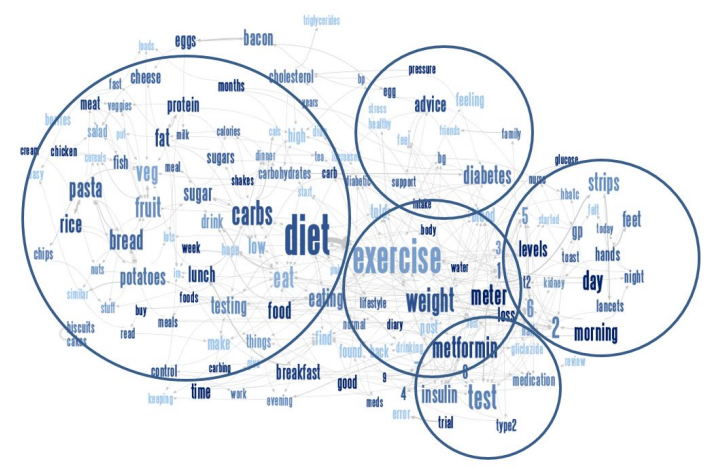

[Fig. 1] Phrase Net Visualization shows any two words that are often associated next to one another with a conjunction regardless of their part of speech.

'cramp'(181), 'toe'(183), and 'hand'(189) (Appendix 1). These words directly refer to the symptomatic characteristic of T2D: the words 'blood', 'sugar', 'level', and 'insulin' indicate that the typical symptoms of diabetes are unstable blood sugar (glucose) levels and insufficient insulin levels. The word 'cramp' was associated with the side effects and 'complication' in the body parts such as 'foot', 'toe', 'eye', and 'kidney'. The word 'cramp' was often considered by the patients as a consequence of physical activity such as workout, driving, and typing, and as the side effects of drugs metformin in particular. Specifically, the words 'toe' and 'eye' are related with the impairment of microcirculation, which is a representative diabetes-mediated cardiovascular complication. The lexically suggested relationship among adjacent words confirms that T2D is a disease that causes extensive complications in the cardiovascular system.

\subsection{Medication}

In this category, the most frequent words are 'insulin'(14) and 'metformin'(23). These two words indicate that either/both insulin or/and metformin are commonly prescribed to T2D patients by their physician for the purpose of diabetes treatment. 'Statin' 
(184) is a representative cholesterol-lowering drug. Thus, the word, 'statin' indicates that it is also a frequently prescribed medication along with diabetic medications for T2D patients because they are likely to have higher cholesterol levels than other healthy people.

\subsection{Psychological Condition}

In the category of 'Psychological Condition,' 'shock'(125) was ranked first among the nouns related to the patients' sentiments, followed by 'worry' (145) and 'stress'(173). 'Shock' is often expressed in relation to the first diagnosis of T2D and to the reading taken after the medical treatment and exercise. For example, the patients tended to describe their experience with T2D diabetes, first when they are diagnosed as having Type 2 Diabetes (as in, "Yes it's a shock to find out you have diabetes," and, "For anyone who knows me that would be a hell of a shock."), and second after the reading the blood level (as in, "I thought that the exercise was a panacea. Then I tested one day last spring, and I got a shock," and, "2 hrs later and [after] a 30 min walk reading was 8.1 :shock:")

Other key words related to the patients' psychological condition were 'stress' and 'worry' (as in, "My average readings are between 4.9 and 6 but last few days getting 7.2 why would that be I've not changed my diet. Only thing is stress levels up," and, "Older drugs such as gliclazide can help and they don't have the pancreatic cancer worries.").

Other keywords with high frequency were the terms associated with getting help and support such as 'advice'(29), 'forum' (36), information' (45) and 'help' (71), with variations such as 'question'(49), 'idea'(55), and 'answer'(180) (Appendix 1).

The five categories of Diet, Exercise, Symptoms, Medication, and Psychological Condition were approximately consistent in coverage when the 400 forum samples were presented using the Phrase Net
Visualization.

\subsection{N-gram Analysis and Recurring Patterns}

Though the patients' psychological condition was moderately reflected in the high frequency key nouns, we performed 3-gram analysis to see the phrase patterns. First, based on 300,496 phrase tokens, we extracted the most frequent 200 phrase types (that is, 8,286 phrase tokens). As the results show in (Appendix 2), 2,590 phrase tokens belong to the described psychological condition, comprising 31 percent of the all 8,286 phrase tokens. The percentage is estimated to be significant when considering the 3-gram phrases capture any three words that are consecutively arranged, including any daily expressions. Mostly, the feelings have to do with a possibility, security, capability, necessity, and a wish, which the patients are expected to perform or participate in, but feel unable to engage in active performance and participation. Based on the results, dominant psychological conditions are categorized into feeling of (a) Negation (for instance, 'I don't' or 'I didn't'), (b) Capability ('not able to' or 'I can't'), (c) Certainty ('if you have' or 'seem to be'), (d) Necessity ('I need to' or 'you need to'), (e) Duty ('I have to' or 'I had to'), and (f) Wish ('would like to' or 'I want to').

\section{DISCUSSION}

There are two major points noteworthy in the results of this analysis. First, we identified major psychological concerns and needs of the T2D patients; and second, online archives of the patients with the same disease can be a useful resource to analyze the patients' discourse.

Based on 200 nouns with the highest frequency from a total of 56,162 T2D related nouns, we identified five thematic categories of Diet, Exercise, Symptom, 
Medication, and Psychological Condition, which are the major areas of the T2D patients' conversation. The category of 'Diet' is identified to be the most dominant concern of the T2B patients. The patients were most concerned with 'carbohydrates' often exemplified as 'pasta', 'rice', 'potato', and 'bread', which are known to be high in carbohydrates (Appendix 1, Figure 1). In the conversations, 'diet' was often associated with 'exercise,' most frequently in the form of 'diet and exercise' with some overlapping issues such as 'weight' and 'lifestyle' as shown in the Phrase Net Visualization (Figure 1).

T2D patients' concerns in the category of 'Symptom' are related to such body parts as 'hand,' 'foot,' 'eye,' 'knee,' and 'kidney.' The T2D patients also go through psychological needs for 'support,' 'advice,' and 'information': they often felt confusion with the information they have and desired to have more information from patients with the same experience, and needed clear and reliable information as pointed out by the qualitative studies done by Kinmonth and Goyder [10], [11]. The words such as 'anyone'(54) and 'someone'(62) also occurred frequently when T2D patients are in need of help or information; they often tried to find someone with the same experience or relevant information as in, "Can anyone help me break my vicious cycle?" "Has anyone got any diabetic friendly snacks?" "I hope someone comes along who has been where you are now to tell you how they coped," and, "Can someone out there who has had a diagnosis of neuropathy enlighten us to the first signs?" Their desire for getting information and finding a person with the same experience or relevant knowledge has to do with the lack of immediate solutions and answers outside the clinic or hospital.

The results imply that detailed and clear information provided in a timely manner is a crucial aspect of patients' need regarding health care service providers, and that digital forums, blogs, and other web-based platforms are the sites where the patients circulate information, share experience, and ask for advice from T2D patients. Therefore, it can be suggested that the websites can be a primary and effective place where T2D patients can be educated about diabetes care, informed about different treatments and supported emotionally.

Regarding the patient's psychology and emotional needs, 'shock' appears to be the word that best describes the state of the patients. The finding is consistent with previous qualitative studies that found that 'shock' represented the primary and prevailing emotion when people were diagnosed with T2D [12], [13] and is also the sign for 'a degree or intensity of emotion with which an individual is unable to cope' [12].

The patients' general attitudes and emotions towards the experience of $\mathrm{T} 2 \mathrm{D}$ were also identified with 3-gram analysis and classified into five categories of Negation, Capability, Necessity, Duty and Wish. As shown in the analysis, 'Negation' ('I don't,' 'I am not,' or 'I didn't') is the most frequent sentiment in the category of phrase analysis. The patients often expressed negative attitudes towards their condition related to T2D as in, "I am not satisfied with that anymore," and, "I don't find it easy to afford strips as I'm a pensioner," or they were in confusion or experienced a lack of knowledge as in, "I'm spiralling downwards and don't know how to stop," and, "I am not sure about a cure, I have read about cures, but doesn't it have something to do with the pancreas?"

The findings are also consistent with previous qualitative studies that showed that patients tend to have more negative attitudes and less ability to control [14], [15], [16]. For instance, Egede et al. argued that the T2B patients tend to show "lower self-care ability, lower self-care adherence, negative attitudes, and less perceived ability to control" [4].

Another dominant feeling that the patients undergo 
is 'Capability' issue as in, "I can't exercise because of chronic arthritic pain, so any ideas would be really helpful," or, "Sadly diabetes can't be cured." As indicated in the (Appendix 3), besides 'Negation' and 'Capability,' expressions related to 'Certainty,' 'Necessity,' 'Duty' and 'Wish' comprise a large portion of the sentiment.

Though not included in the categories of 'Psychological Condition', 3-gram results also show that patients typically suffer from T2D for a considerable time. The duration phrases (560 phrase tokens, ranked second in the 3 gram analysis) such as 'I have been' and 'I have had' were distinctive in the results, and it indicates that T2D patients may have been in the status described for a period time and their symptoms may be described as chronic. The present perfect tense was often used when referring to the period of time from being diagnosed as having T2D as in, "I have been type 2 for over five years and at the moment I'm running at around 6.0," and, "I have been diabetic for 13 years and this tear has been a hard lesson in relearning what I can and cannot eat," or to the patient's physical state such as obesity as in, "i have been overweight most of my life but being told i was diabetic sort of shocked me into doing something about it," and medical treatment as in, "I have been on $2 \mathrm{x}$ metformin twice a day for 3 months." The chronic condition is reinforced when accompanied by the high frequency of the noun 'year' (11) suggesting that T2D is a long-lasting disease.

The nouns of highest frequency in the category of 'Psychological Condition' and additional 3-gram phrases indicate that the overall sentiment of the patients revolves around the sense of inability and instability. Despite the recognition of the need for life style change, this feeling of inability with the sense of depression and loss of control also permeated the online discourse of the T2D patients as previously pointed out by the qualitative studies of Gabbay el al. and Peyrot et al. [17], [18].

Since the psychological conditions bordering on depression and compulsion such as overeating, impulsive food-seeking, and incessant checking blood glucose, it is of paramount importance that health professionals understand the ways to communicate the control issues with T2D patients because these feelings and behaviors can increase the risk of intensifying diabetes. The findings also support the previous studies that depression and compulsiveness in the patients' behavior can increase the risk of worsening diabetes and obesity [19], [20], [21], [22].

This study also demonstrates that it is possible to understand the interests and concerns of T2D patients' online discourse through text-mining technology. The results of the online discourse analysis showed the possibility of recognizing key words from a large database of texts. By understanding the major issues and concerns of the patients, medical professionals can increase their effectiveness when educating them. The preference for and dominance of online discourse are expected to continue or accelerate since T2D patients want to escape from pain and the feeling of inability, search for advice online, converse about medical treatment, and get support from others.

Despite the importance of quantitative online discourse analysis, there are some limitations to this study. First of all, though quantitative analysis based on keyword extraction and N-gram can help researchers deal with a large amount of information about a group of patients' online discourse, it is not definitive, and it is uncertain whether it may lead to clinical and diagnostic confirmation. Additionally, the sets of information on age, gender, occupation of patients were not specified, simplifying the complexity of individual disease patterns and processes. Further, the T2D discourse archived in the website that is intended to appeal to the people in the United Kingdom does not represent a guarantee of demographic coverage. 


\section{CONCLUSION}

This paper has identified five major categories of the T2D patients' concerns based on an online forum where the patients voluntarily verbalized their naturally occurring emotional reactions and concerns related to T2D. We have emphasized the fact that the lexical and phrasal analysis brought to the forefront the prevailing negative reactions and desires for clear information, professional advice, and emotional support. This study used lexical and phrasal analysis based on text-mining tools to estimate the potential of using a large sample of patient conversation of a specific disease posted on the internet for clinical features and patients' emotions. As a result, the study showed that when compared to the previous qualitative research, quantitative analysis is a viable method of generalizing the psychological concerns and features from a large dataset of language.

Quantitative analysis of online discourse is considered to be more adequate in capturing the ever-flowing conversation of the T2D patients as there are a growing number of $\mathrm{T} 2 \mathrm{D}$ patients who want to share their experience and information with others regardless of time and location. Though there are some limits in details and in the use of text-mining for diagnostic purposes, quantitative analysis is believed to complement qualitative and ethnographic methods to better understand the general patients' experience of T2D.

\section{REFERENCES}

[1] American Diabetes Association, Economic Costs of Diabetes in the U.S. in 2012, Diabetes Care, vol. 36, no. 4, pp. 1033-1046, 2013.

[2] R. Klein, SE. Moss, BE. Klein, MD. Davis, and DL. DeMets, The Wisconsin Epidemiologic Study of Diabetic Retinopathy. XI. The Incidence of Macular Edema, Ophthalmology, vol. 96, pp. 1501 - 1510,
1989.

[3] UK Prospective Diabetes Study Group, Tight Blood Pressure Control and Risk of Macrovascular and Microvascular Complications in Type 2 Diabetes, British Medical Journal, vol. 318, no.7175, p. 29, 1999.

[4] A. Faulkner, When the News is Bad: a Guide for Health Professionals on Breaking Bad News, Stanley Thornes, Cheltenham, UK, 1998.

[5] L. Fernandez-Luque, R. Karlsen, J. Bonander, Review of Extracting Information from the Social Web for Health Personalization, Journal of Medical Internet Research, vol. 13, no. 1, e15, 2011.

[6] F. Greaves, D. Ramirez-Cano, C. Millett, A. Darzi, and L. Harnessing the Cloud of Patient Experience: Using Social Media to Detect Poor Quality Healthcare, BMJ Quality \& Safety, vol. 22, no. 3, pp. 251-255, 2013.

[7] U. Raja, T. Mitchell, T. Day, and JM. Hardin, Text-mining in Healthcare. Applications and Opportunities, Journal of Healthcare Information Management, vol. 22, no. 3, pp. 52-56, 2008.

[8] Y. Lu, P. Zhang, J. Liu, J. Li, and S. Deng, Health-Related Hot Topic Detection in Online Communities Using Text Clustering, PLoS ONE, vol. 8, no. 2, e56221, 2013.

[9] PR. Vasconcellos-Silva, D. Carvalho, C. and C. Lucena, Word Frequency and Content Analysis Approach to Identify Demand Patterns in a Virtual Community of Carriers of Hepatitis C, Interactive Journal of Medical Research, vol. 2, no. 2, e12, 2013.

[10] EC. Goyder, PG. McNally, M. Drucquer, N. Spiers, and JL. Botha, Shifting of Care for Diabetes from Secondary to Primary Care 1990 - 1995: Review of General Practices, Br Med J., vol. 316, pp. 1505 -6, 1998.

[11] AL. Kinmonth, E. Murphy, and T. Marteau, Diabetes and Its Care-What Do Patients Expect?, J R Coll Gen Pract., vol. 39, pp. 324 - 7, 1989.

[12] I. Jedlicka-Köhler, M. Götz, and I. Eichler, Parents' 
Recollection of the Initial Communication of the Diagnosis of Cystic Fibrosis, Pediatrics, vol. 97, pp. 204 - 209, 1996.

[13] E. Peel, O Parry, M Douglas, and J Lawton, Diagnosis of type 2 diabetes: a qualitative analysis of patients' emotional reactions and views about information provision, Patient Education and Counseling, vol. 53, pp. 269 - 275, 2004.

[14] L. Egede and C. Ellis, The Effects of Depression on Diabetes Knowledge, Diabetes Self-Management, and Perceived Control in Indigent Patients with Type 2 Diabetes, Diabetes Technology \& Therapeutics, vol. 10, no. 3, pp. 213-219, 2008.

[15] J. Kiecolt-Glaser, L. McGuire' T. Robles, and R. Glaser, Emotions, Morbidity, and Mortality: New Perspectives from Psychoneuroimmunology, Annual Review of Psychology, vol. 53, pp. 83-10, 2002.

[16] LJ. Lange and JD. Piette, Perceived Health Status and Perceived Diabetes Control: Psychological Indicators and Accuracy, J Psychosom Res., vol. 58, pp. 129 - 137, 2005.

[17] R. Gabbay, I. Lendel, T. Saleem, G. Shaeffer, A. Adelman, D. Mauger, M. Collins, and R. Polomano, Nurse case management improves blood pressure, emotional distress and diabetes complication screening, Diabetes Research and Clinical Practice, vol. 71, pp. 28 - 35, 2006.

[18] M. Peyrot and R. Rubin, Behavioral and Psychosocial Interventions in Diabetes, Diabetes Care, vol. 30, no. 10, pp. 2433-2440, 2007.

[19] JV. Butler, JE. Whittington, AJ. Holland, H. Boer, D. Clark, and T. Webb, Prevalence of, and Risk Factors for, Physical Ill-health in People with Prader - Willi Syndrome: a Population-based Study, Dev Med Child Neurol., vol. 44, no. 4, pp. 248 - 255, 2002.
[20] AJ. Holland, JV. Butler, JE. Whittington, H. Boer, D. Clark, and T. Webb. Behavioural Phenotypes Associated with Specific Genetic Disorders: Evidence from a Population-based Study of People with Prader - Willi Syndrome, Psychol Med., vol. 33, no. 1, pp. $141-153,2003$.

[21] LE. Levitt Katz, S. Swami, M. Abraham, KM. Murphy, AF. Jawad, H. McKnight-Menci, and R. Berkowitz, Neuropsychiatric Disorders at the Presentation of Type 2 Diabetes Mellitus in Children, Pediatric Diabetes, vol. 6, pp. 84 - 89, 2005. [22] R. Rubin and M. Peyrot, Psychological Issues and Treatments for People with Diabetes, Clin Psychol., vol. 57, pp. 457 - 478, 2001.

\section{황 문 현(Hwang, Moon Hyon)}

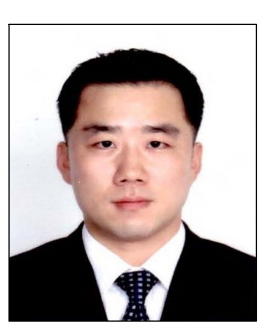

· 1999년 2월 : 고려대학교 체육교육 과 (체육교육학사)

-2001년 2월 : 고려대학교 대학원 체 육학과(체육학석사)

-2014년 8월 : 미국 University of Florida, Dept. of Applied Physiology and Kinesiology(이학 박사 졸업예정)

· 관심분야 : 운동처방, 스포츠의학, 심혈관질환, 만성대사 성질환

•E-Mail : mhhwang@ufl.edu

박 정 식(Park, Jungsik)

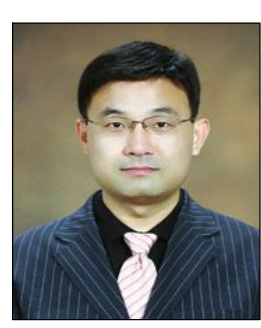

· 1994년 2월 : 서강대학교 영문학과 (문학사)

· 1999년 2월 : 미국 City University of New York at Queens 영문학과 (문학석사)

-2006년 5월 : 미국 Texas A\&M University 영문학과 (문학박사) - 2008년 3월 현재 : 아주대학교 영문학과 부교수

· 관심분야 : 스토리텔링, 텍스트마이닝, 미국소설

·E-Mail : jspark@ajou.ac.kr 
텍스트마이닝 기법을 이용한 제 2형 당뇨환자 온라인 담론의 어휘 및 구문구조 분석

Appendix 1. Nouns with Highest Frequency

\begin{tabular}{|c|c|c|c|c|c|c|c|c|}
\hline Rank & Frequency & Noun & Rank & Frequency & Noun & Rank & Frequency & Noun \\
\hline 1 & 1624 & carb & 36 & 238 & forum & 71 & 123 & help \\
\hline 2 & 995 & blood & 37 & 237 & morning & 72 & 119 & water \\
\hline 3 & 955 & day & 38 & 233 & medication & 73 & 116 & everyone \\
\hline 4 & 874 & test & 39 & 215 & bread & 74 & 113 & health \\
\hline 5 & 843 & level & 40 & 215 & hypo & 75 & 112 & $\mathrm{mg}$ \\
\hline 6 & 837 & type 2 & 41 & 213 & tablet & 76 & 111 & dose \\
\hline 7 & 800 & diet & 42 & 200 & anything & 77 & 110 & pasta \\
\hline 8 & 793 & sugar & 43 & 200 & $\mathrm{rrb}^{-}$ & 78 & 107 & moment \\
\hline 9 & 727 & time & 44 & 198 & post & 79 & 103 & $\mathrm{~g}$ \\
\hline 10 & 653 & diabetes & 45 & 197 & information & 80 & 102 & walk \\
\hline 11 & 630 & year & 46 & 186 & life & 81 & 102 & cholesterol \\
\hline 12 & 596 & food & 47 & 178 & breakfast & 82 & 102 & hospital \\
\hline 13 & 573 & doctor & 48 & 176 & vegetable & 83 & 102 & nothing \\
\hline 14 & 536 & insulin & 49 & 171 & question & 84 & 102 & portion \\
\hline 15 & 517 & meal & 50 & 170 & night & 85 & 102 & egg \\
\hline 16 & 502 & weight & 51 & 164 & cd \% & 86 & 102 & foot \\
\hline 17 & 444 & problem & 52 & 158 & number & 87 & 101 & condition \\
\hline 18 & 434 & reading & 53 & 157 & luck & 88 & 98 & part \\
\hline 19 & 434 & month & 54 & 156 & anyone & 89 & 97 & appointment \\
\hline 20 & 403 & glucose & 55 & 152 & idea & 90 & 97 & lunch \\
\hline 21 & 398 & exercise & 56 & 147 & work & 91 & 96 & fat \\
\hline 22 & 394 & gp & 57 & 146 & drug & 92 & 96 & home \\
\hline 23 & 359 & metformin & 58 & 145 & $\mathrm{im}$ & 93 & 96 & pain \\
\hline 24 & 358 & testing & 59 & 144 & potato & 94 & 95 & change \\
\hline 25 & 343 & hour & 60 & 143 & stone & 95 & 94 & feeling \\
\hline 26 & 326 & control & 61 & 143 & prescription & 96 & 94 & person \\
\hline 27 & 324 & effect & 62 & 142 & someone & 97 & 94 & pressure \\
\hline 28 & 317 & meter & 63 & 140 & diagnosis & 98 & 91 & reason \\
\hline 29 & 310 & advice & 64 & 138 & today & 99 & 89 & bs \\
\hline 30 & 310 & week & 65 & 132 & loss & 100 & 89 & chocolate \\
\hline 31 & 275 & bg & 66 & 130 & everything & 101 & 89 & end \\
\hline 32 & 263 & something & 67 & 127 & rice & 102 & 89 & fact \\
\hline 33 & 261 & nurse & 68 & 125 & amount & 103 & 89 & family \\
\hline 34 & 260 & body & 69 & 124 & fruit & 104 & 89 & intake \\
\hline 35 & 249 & result & 70 & 124 & eye & 105 & 89 & reply \\
\hline
\end{tabular}


Appendix 1. Nouns with Highest Frequency (continued)

\begin{tabular}{|c|c|c|c|c|c|c|c|c|}
\hline Rank & Frequency & Noun & Rank & Frequency & Noun & Rank & Frequency & Noun \\
\hline 106 & 86 & issue & 138 & 62 & support & 170 & 44 & neuropathy \\
\hline 107 & 84 & difference & 139 & 61 & alcohol & 171 & 44 & situation \\
\hline 108 & 83 & friend & 140 & 61 & one & 172 & 44 & soup \\
\hline 109 & 82 & husband & 141 & 60 & energy & 173 & 44 & stress \\
\hline 110 & 82 & gliclazide & 142 & 58 & lifestyle & 174 & 44 & wife \\
\hline 111 & 81 & milk & 143 & 58 & money & 175 & 43 & knee \\
\hline 112 & 80 & stuff & 144 & 57 & resistance & 176 & 43 & kidney \\
\hline 113 & 80 & cake & 145 & 57 & worry & 177 & 43 & oil \\
\hline 114 & 79 & cheese & 146 & 56 & stress & 178 & 43 & complication \\
\hline 115 & 78 & news & 147 & 55 & fish & 179 & 43 & start \\
\hline 116 & 77 & fasting & 148 & 55 & need & 180 & 42 & answer \\
\hline 117 & 77 & meat & 149 & 55 & roll & 181 & 42 & cramp \\
\hline 118 & 76 & lbs & 150 & 54 & check & 182 & 41 & hope \\
\hline 119 & 76 & liver & 151 & 54 & toast & 183 & 41 & toe \\
\hline 120 & 76 & surgery & 152 & 54 & website & 184 & 41 & statin \\
\hline 121 & 76 & tea & 153 & 53 & clinic & 185 & 41 & target \\
\hline 122 & 75 & evening & 154 & 53 & protein & 186 & 41 & thumbup \\
\hline 123 & 75 & experience & 155 & 52 & drink & 187 & 41 & step \\
\hline 124 & 75 & porridge & 156 & 51 & tomorrow & 188 & 40 & bacon \\
\hline 125 & 75 & shock & 157 & 50 & carbing & 189 & 40 & hand \\
\hline 126 & 75 & patient & 158 & 50 & lrb & 190 & 40 & diary \\
\hline 127 & 74 & eating & 159 & 50 & practice & 191 & 39 & version \\
\hline 128 & 73 & care & 160 & 49 & risk & 192 & 39 & consultant \\
\hline 129 & 73 & stomach & 161 & 48 & cream & 193 & 39 & wheat \\
\hline 130 & 72 & treatment & 162 & 48 & dinner & 194 & 37 & age \\
\hline 131 & 71 & salad & 163 & 48 & disease & 195 & 37 & chance \\
\hline 132 & 69 & heart & 164 & 48 & head & 196 & 36 & joint \\
\hline 133 & 68 & place & 165 & 48 & nhs & 197 & 36 & knowledge \\
\hline 134 & 67 & figure & 166 & 47 & monitor & 198 & 36 & salt \\
\hline 135 & 65 & pancreas & 167 & 47 & regime & 199 & 35 & appetite \\
\hline 136 & 64 & sleep & 168 & 47 & review & 200 & $<$ null $>$ & $<$ null $>$ \\
\hline 137 & 63 & chicken & 169 & 45 & mile & & & \\
\hline
\end{tabular}


Appendix 2. 3-gram Analysis of Phrase Patterns

\begin{tabular}{|c|c|c|c|c|c|c|c|c|}
\hline Rank & Freq & 3-gram & Rank & Freq & 3-gram & Rank & Freq & 3-gram \\
\hline 1 & 296 & I don $\mathrm{t}$ & 34 & 52 & all the time & 67 & 40 & don $t$ think \\
\hline 2 & 161 & I have been & 35 & 51 & $\mathrm{I}$ haven $\mathrm{t}$ & 68 & 40 & I think it \\
\hline 3 & 131 & a lot of & 36 & 51 & seem to be & 69 & 40 & If you are \\
\hline 4 & 124 & I was diagnosed & 37 & 51 & that I have & 70 & 40 & need to be \\
\hline 5 & 114 & I ve been & 38 & 50 & you have to & 71 & 39 & and it $\mathrm{s}$ \\
\hline 6 & 105 & you need to & 39 & 49 & I need to & 72 & 39 & seems to be \\
\hline 7 & 99 & be able to & 40 & 48 & and I am & 73 & 38 & a day and \\
\hline 8 & 95 & I $\mathrm{m}$ not & 41 & 48 & if you have & 74 & 38 & but it $\mathrm{s}$ \\
\hline 9 & 92 & if you are & 42 & 48 & on this forum & 75 & 38 & I wouldn $\mathrm{t}$ \\
\hline 10 & 91 & a couple of & 43 & 48 & one of the & 76 & 38 & in the UK \\
\hline 11 & 89 & $\mathrm{I}$ can $\mathrm{t}$ & 44 & 48 & to be a & 77 & 38 & some of the \\
\hline 12 & 85 & blood sugar levels & 45 & 48 & you have a & 78 & 37 & that I am \\
\hline 13 & 85 & don $t$ know & 46 & 47 & the amount of & 79 & 37 & they don $\mathrm{t}$ \\
\hline 14 & 83 & I am not & 47 & 46 & I am a & 80 & 36 & I m sure \\
\hline 15 & 81 & at the moment & 48 & 46 & I think I & 81 & 36 & need to test \\
\hline 16 & 80 & you don $\mathrm{t}$ & 49 & 46 & if you can & 82 & 36 & $\mathrm{t}$ seem to \\
\hline 17 & 75 & I have a & 50 & 46 & to the forum & 83 & 36 & the end of \\
\hline 18 & 74 & I have to & 51 & 45 & I was told & 84 & 35 & blood glucose levels \\
\hline 19 & 70 & I didn $t$ & 52 & 44 & that you have & 85 & 35 & I used to \\
\hline 20 & 66 & a bit of & 53 & 44 & when I was & 86 & 35 & I was on \\
\hline 21 & 62 & in the morning & 54 & 44 & with type diabetes & 87 & 35 & most of the \\
\hline 22 & 59 & don $t$ have & 55 & 43 & have to be & 88 & 35 & my BG levels \\
\hline 23 & 59 & I had a & 56 & 43 & I ve had & 89 & 35 & to see the \\
\hline 24 & 59 & low carb diet & 57 & 43 & there is a & 90 & 34 & and I have \\
\hline 25 & 59 & to have a & 58 & 43 & was diagnosed with & 91 & 34 & for a while \\
\hline 26 & 57 & and I m & 59 & 42 & $\mathrm{I} \mathrm{m} \mathrm{a}$ & 92 & 34 & go back to \\
\hline 27 & 57 & I have had & 60 & 42 & $\mathrm{t}$ want to & 93 & 34 & I know I \\
\hline 28 & 57 & my blood sugar & 61 & 42 & to see if & 94 & 34 & I $m$ on \\
\hline 29 & 55 & as well as & 62 & 41 & I have lost & 95 & 34 & need to get \\
\hline 30 & 53 & diet and exercise & 63 & 41 & in the $\mathrm{s}$ & 96 & 34 & times a day \\
\hline 31 & 53 & I had to & 64 & 41 & put me on & 97 & 34 & to see what \\
\hline 32 & 53 & that you are & 65 & 40 & a low carb & 98 & 33 & is a good \\
\hline 33 & 53 & your blood sugar & 66 & 40 & diagnosed with type & 99 & 33 & it $s$ not \\
\hline
\end{tabular}


Appendix 3. Dominant Psychological Conditions

\begin{tabular}{|c|c|c|c|}
\hline Category & \# of tokens & Percentage & Sentence examples \\
\hline Negation & 1215 & $\begin{array}{l}0.146633 \\
(14.6 \%)\end{array}$ & $\begin{array}{l}\text { 'I don't find it easy to afford strips as I'm a pensioner.' } \\
\text { ' } I \text { 'm spiralling downwards and don't know how to stop.' }\end{array}$ \\
\hline Capability & 345 & 0.041636 & $\begin{array}{l}\text { 'I can't handle them at all at present.' } \\
\text { 'like most type2 diabetics, you are not able to metabolise them efficiently.' }\end{array}$ \\
\hline Necessity & 288 & 0.034757 & $\begin{array}{l}\text { 'We really need to know a bit more about your daily levels, fasting each } \\
\text { morning, pre and post prandial levels, bedtime level.' } \\
\text { 'It all takes time and we all so desperately need patience.' }\end{array}$ \\
\hline Certainty & 394 & 0.04755 & $\begin{array}{l}\text { 'I am wondering if you have changed anything.' } \\
\text { 'My trouble is controlling my overnight BS often waking with bs in the } 8 \text { to } \\
10 \text { range, have tried not eating before I go to bed and also eating before bed, } \\
\text { both of which dont seem to make any difference.' }\end{array}$ \\
\hline Duty & 220 & 0.026551 & $\begin{array}{l}\text { 'I have to increase my lipotar currently taking Aprrovel } 10 \mathrm{mg} \text {.Really struggling } \\
\text { to get control of blood sugars.' } \\
\text { 'I have also struggled with high bp for many years and I have to take } 5 \text { different } \\
\text { drugs each day for my bp.' }\end{array}$ \\
\hline Wish & 128 & 0.015448 & $\begin{array}{l}\text { 'I only wish I had known about this earlier, could have saved myself a lot of } \\
\text { grief.' } \\
\text { 'As I said I want to be able to carry on with my life abeit at a slower pace } \\
\text { without having any complications.' }\end{array}$ \\
\hline Total & 2590 & 0.312575 & \\
\hline
\end{tabular}

